\title{
Uniting Academic Workers: Graduate Workers Organize with the United Auto Workers
}

\author{
Lindsey Dayton \\ Columbia University \\ Rudi Batzell \\ Harvard University
}

On Friday December 9, 2016, Columbia teaching and research assistants elected the Graduate Workers of Columbia-United Auto Workers (GWC-UAW) Local 2110 as their union with 1602 yes and 623 no votes. ${ }^{1}$ On December 22, a preliminary count for the Harvard Graduate Students Union-UAW was not conclusive, with 314 challenge ballots exceeding the margin between 1,272 yes and 1,456 no votes. $^{2}$ Both elections were possible because the National Labor Relations Board, ruling on a suit brought by Columbia students, overturned a 2004 decision that prohibited the formation of graduate unions in private colleges and universities. $^{3}$

Graduate student unionism is typically understood as the latest battle in a long war over the "corporatization of the university," a process by which university administrations began, in the 1980s, to think of postsecondary education as an "emerging market" that can be measured in terms of "income outcome" instead of a public good premised on the preparation of critical, informed, and civic-minded democratic subjects. ${ }^{4}$ Graduate worker unionization efforts are not only a response to economic restructuring in higher education, but also a part of struggles to expand and protect democratic possibilities in the postwar United States.

"Corporatization" has had many effects on the university, but one that especially frustrates graduate students is the way a model of competition in academic labor (for scarce teaching positions and grant funding) works handin-hand with the formulation of undergraduate students as consumers to make graduate teaching and research assistants indispensable, invisible, and precarious all at once. The decline of full-time faculty positions, seen in the corresponding explosion of adjunct teaching and postdoc research positions and the shrinking pool of tenured faculty and grant-funded principal investigators (PIs), has, as any graduate student nearing completion can tell you, put enormous pressure on PhDs. ${ }^{5}$ The flexibility - precarity - generated by a competitive labor market is a symptom of a great divide between the vision of higher education as a public good, a cause worthy of the sacrifice of many years of apprenticeship, held by many faculty members, and the reality of higher education as economic enterprise that flourishes on a flexible and cheap pool of teaching and research work provided by graduate students, adjuncts, and postdocs. 
While this organization of work may bolster university administrative careers, it is harmful to the production and dissemination of knowledge, the twin missions of the university.

Still, an exclusive focus on the economic restructuring of universities since the 1980s ignores the politics of the postwar period. We recount here a brief history of graduate unionization at Columbia and Harvard-and the vision of democratic participation that informs our work as researchers and teachers as well as our organizing - as part of a campus politics whose vision of the university was forged in postwar social movements. It is this vision of the university, as a space of radical possibility, that corporatization threatens, but we should not forget that its threat is political as well as economic. After all, Ronald Reagan began his career as California governor in 1966 by combining a crusade against welfare and taxes with an attack on Berkeley radicals. These were not separate policy initiatives but a single reframing of publicly funded higher education as a form of welfare for a dissolute left. By reducing state funding for California's tuition-free system of higher education, Reagan chopped away at an institution that, in the hands of leftist academics he argued, had the potential to foster a radical redistribution of power and resources. ${ }^{6}$

The recent campaigns at Columbia and Harvard built upon decades of organizing. While administrators have claimed since the 1960s that the "adversarial" process of collective bargaining has no place at universities, graduate workers themselves have long recognized the need to join together to have a more powerful voice in the conditions of their labor. ${ }^{7}$ Graduate students at Harvard first considered forming their own union in 1966. The issues of concern included a "liveable wage," workman's compensation (a cyclotron explosion injured several teaching fellows who received no compensation), "a pernicious spirit of competition [that] alienates graduate students from each other," and unilateral decision-making by administrators. ${ }^{8}$ Nevertheless, like today, some graduate workers were ambivalent about forming a union. Interestingly, their same concerns have reappeared in subsequent campaigns. A union might raise "the spectre of Berkeley" and campus radicalism, a strike might alienate "moderate teaching fellows," the effort would "guarantee administration and faculty hostility," and there were doubts about bringing in an established international union.

The "death blow" to talk of a union came when students learned that the NLRB, based on the 1951 Columbia decision, did not include university employees under its jurisdiction because "charitable organizations" were exempt. ${ }^{9}$ The organizers moved forward as an amorphous "Federation," which the administration rebuffed. ${ }^{10}$ Nevertheless, the pressure of collective organization had some effect. By 1971, for example, grad workers had seen the "third increase within 6 years" in stipends. ${ }^{11}$ In fact, this first union effort was not dead yet. In the spring of 1972 a unilateral change to Teaching Fellow compensation prompted a sustained and militant effort to win a union for the graduate student teaching staff at Harvard. ${ }^{12}$ After an announcement of cuts to a scholarship program, an open meeting of hundreds voted to form a union, and the 
organizing committee signed up more than one thousand supporters and organized two short work stoppages - of one day and two days-over the course of the spring semester. ${ }^{13}$ The organizers resolved to only meet with the university "as a recognized union for the purposes of collective bargaining." 14 The following spring, after an unsuccessful strike, organizers began collecting authorization cards to petition the NLRB for recognition. Unsurprisingly, given the union's strike defeat, the organizers managed to sign only around ten percent of the teaching staff and abandoned the effort soon after. ${ }^{15}$ These efforts at Harvard were part of a broader unionization effort in the 1970s, but unions were secured in only the universities of Oregon, Wisconsin, and Michigan. ${ }^{16}$

The next wave of graduate student unionization began in the 1990s and early 2000s, when the UAW emerged as the leading ally for graduate student organizers. The roots of these campaigns extended to earlier confrontations in the labor movement and in the university over the devaluation of professional and white-collar labor. The UAW's role in these new campaigns emerged from a partnership forged in the early 1980s when New York's District 65 joined with the UAW. The independent District 65 formed in the 1930s and 40s out of organizing drives among low-wage immigrant retail clerks, and by the 1970s and 80s had become a major player in university clerical worker campaigns. ${ }^{17}$ As Lisa Phillips shows, District 65 was one of the UAW's few partners in a short experiment in massive new organizing in new sectors that broke from the AFL-CIO, the Alliance for Labor Action. The death of Walter Reuther, the UAW leader who spearheaded this effort, led to the demise of the independent Alliance for Labor Action, but it forged a connection between the two unions. After District 65 affiliated with the UAW, the union organized graduate students across the campuses of the Universities of California and Massachusetts. No stranger to long-term organizing commitments, the UAW has litigated state labor board decisions in California, Massachusetts, Washington, and Connecticut and has also litigated every national NLRB case on student worker jurisdiction, including the 2000 NYU decision, the 2004 Brown decision, and now the 2016 Columbia decision. ${ }^{18}$

Graduate workers in the UAW draw on the experiences of remarkable organizers who pioneered white-collar and higher-education organizing. Foremost among them are Julie Kushner, currently the president of UAW Region 9A, and Maida Rosenstein, current president of UAW Local 2110. Both Kushner, as a District 65 organizer, and Rosenstein, as a clerical worker and organizing committee member, were at the heart of the 1980 s clerical workers organizing drive at Barnard and Columbia, widely recognized for breaking new ground in terms of strategy, mass-participation by workers, and innovative contracts that addressed sexism and racism. ${ }^{19}$ The strategies and lessons learned from this campaign were crucial for the future of grad worker organizing. Like graduate students, clerical workers were divided by departments spread across more than forty different buildings. As with grad workers, many clerical workers had "close working relationships with faculty," and organizers had to demonstrate that their fight was with the administration, 
where the power and resources of the university were increasingly concentrated. ${ }^{20}$ When Julie Kushner joined the clerical union campaign as a staff organizer for District 65, she worked to expand the organizing committee and ensure that it reflected the diverse racial, ethnic, and gender composition of the unit, and included representatives from all of the major buildings on campus. ${ }^{21}$ An expanded organizing committee of 125 enabled direct one-on-one outreach to every worker in the unit, and the committee created a newsletter to keep supporters informed as the campaign developed. And as with graduate workers, the university litigated and delayed relentlessly. District 65 filed for an election in March 1981, but the vote was delayed until May 1983; the union won by a narrow margin, and the university challenged nearly 100 ballots. It was not until October 1985, after the union had decisively manifested its powerful majority support in a five-day strike, that the clerical workers at Columbia won a contract that met all their major demands. ${ }^{22}$ The organizing drive had exposed glaring racist and sexist hierarchies of job description, pay, and promotion, which the union's first and subsequent contracts addressed. While every campaign reflects the work and experiences of that shop, District 65's clerical campaigns helped build an organizing strategy that would help graduate students win at private universities like Columbia and Harvard. Thus, in 1997 when Julie Kushner received a call from NYU graduate students, the UAW was ready to support a campaign that would restore collective bargaining rights for student employees at private universities in $2000 .^{23}$

Like the clerical workers' campaign, the graduate worker organizing of the early 2000 s bears an eerie resemblance to that of our own moment. Privatesector graduate unions received a green light to move forward with certification elections with the $N Y U$ decision, which Bush-appointees to the NLRB would overturn in the 2004 Brown decision. ${ }^{24}$ While NYU's Graduate Student Organizing Committee (GSOC-UAW) won their certification election and successfully negotiated a first contract in this short window after Brown, the NLRB impounded uncounted ballots from nearly concurrent elections at Columbia and Brown. At Cornell a student antiunion campaign mobilized enough doubt to defeat the union in a certification election with 1,351 no votes against only 580 yes votes. ${ }^{25}$

In the fall of 2000, graduate workers at Columbia turned to UAW Local 2110, the direct descendant of District 65, because of its considerable experience with campus organizing, including at Columbia itself. While Columbia administrators argued that a union would create an "adversarial" relationship and disrupt the "collegial interaction between teachers and students," 2110's president Maida Rosenstein, a veteran of Columbia's clerical organizing drive, recognized new wine in old bottles: two decades earlier, the administration had claimed that clerical unionization would disrupt the special relationship between a secretary and boss. ${ }^{26}$

Antiunion arguments that played a leading role in previous campaigns came to the fore after 2000, but Columbia administrators went beyond simply dismissing the idea of graduate students as workers. With other universities 
facing the possibility of a graduate union, Columbia deployed a sophisticated cocktail of student-led and lawyer-orchestrated antiunion tactics. An op-ed in Columbia's student newspaper in 2002 shows the core of the antiunion message coming into focus. Grads "will be forced to pay dues to an organization that is undemocratic and prejudiced as well as which denies our votes." 27 Another common tactic was to raise the stakes of a certification election. A vote against the union means more time for discussion, while a vote for the union locks in a binding, coercive relationship. "Once a union is installed, there is no turning back." Perhaps the ugliest face of the campaigns run by university administrations against union drives has been their repeated efforts to target international students to create fear. ${ }^{28}$ Antiunion students amplify these divide-and-conquer tactics by focusing on visa fears and trumpeting the claim that the UAW "has historically discriminated against foreign skilled workers." 29

A powerful, coherent, and effective antiunion message played a major role in shaping graduate student elections in the early 2000s, which continues to this day. At Harvard this year, the administration facilitated the creation of a large and well organized student group that mobilized a powerful opposition to the union. The campaign was based on a playbook developed fifteen years ago by Lennart Erickson, a graduate student in economics, who launched the "At What Cost?" campaign against the union at Brown and has since emerged as a leader of the antiunion effort across the northeast. ${ }^{30}$ Erickson formulated a strategy that Columbia and Harvard administrators (along with those at the University of Chicago, Brown, Northwestern, and others) pulled off the shelf once again to obstruct the recent graduate union drives. ${ }^{31} \mathrm{He}$ encouraged antiunion organizers to align a union with a "confrontational relationship" and dues guaranteed to go "to an international union" that would provide "little in return"; characterized basic on-the-ground organizing in labs and offices as harassment; dismissed union elections as illegitimate because they excluded graduate workers outside of the bargaining unit; and highlighted the international union's "stance on environmental and immigration issues.",32

Erickson was not alone, however. The coherence of university messages and the antiunion student groups that they encourage and facilitate points to a force uniting different administrations: the law firms representing universities in union campaigns. Antiunion law firms provide an antiunion blueprint and coordinate antiunion activities across schools. After Columbia's Graduate Student Employees United (GSEU-UAW) filed a petition for a certification election, the administration hired Proskauer Rose, a virulently antilabor law firm that had negotiated against the Columbia clerical workers in the 1980s. ${ }^{33}$ Edward Brill, part of the Columbia team in 2001, leveraged his experience fighting the graduate union in the early 2000s to develop a career as a specialist in university litigation against student workers; once again, he represents Columbia as it tries to undo the victories of the current graduate worker campaign. $^{34}$

Organizing committees at Columbia and Harvard prepared carefully for At What Cost? and corporate antiunion tactics. They spent thousands of 
painstaking hours on the ground to build a deep network of department organizers and leaders and prepped them well in advance on the tactics of the eleventh-hour union smear campaign. With the institutional memory of the UAW, we knew what to expect, and there were few surprises. Coordination between our two campaigns also bolstered our edge. Columbia and Harvard often lifted the same antiunion strategies from earlier campaigns and from one another-plagiarized, an academic might say.

In addition to the experience of veteran organizers who came out of District 65 and witnessed the first graduate worker campaign of the 2000s, the commitment of the UAW international was of existential importance, not only to our campaigns, but to the most recent wave of graduate worker organizing as a whole. In the wilderness between the 2004 Brown reversal and the 2016 Columbia decision, graduate campaigns struggled to maintain active organizing in the absence of collective bargaining rights. Most international unions cut back material support, withdrawing staff organizers and legal resources even as they preserved a notional commitment to organizing graduate workers in the private sector. ${ }^{35}$ The hostility of the NLRB shifted the rank-and-file strategies of surviving unions from collective bargaining and toward either issue-based campaigns to improve graduate quality of life and working conditions or more abstract discussions of academic labor. ${ }^{36}$ Many campaigns disappeared altogether. In 2013, NYU and GSOC-UAW reached an agreement in which the union withdrew its petition for certification to the NLRB; in exchange, the university agreed to a union election. In December 2013, NYU graduate workers voted overwhelmingly in favor of the union: 620 to 10 . With a strong mandate, and the extra nudge of a strike-authorization vote, the union negotiated a contract. GSOC's victories-first in securing an election for recognition and then in securing a contract-inspired envy and energy in private-sector graduate workers at other universities, including our own.

Graduate workers at other private universities could not follow in NYU's footsteps until Brown was overturned. Student workers at Columbia, and then the New School, carried that challenge forward. It took less than a year at Columbia for a large majority of Columbia's more than three thousand graduate students workers to sign authorization cards, which we delivered to the regional NLRB office with New School grad workers in December 2014. Columbia refused to recognize that majority, citing the Brown precedent, and took our union into hearings that lasted through the following spring. The delay in recognition demanded grueling work and dedication from graduate organizers. To maintain our majority support among a workforce with high turnover in the face of an uncertain timeline, we had to organize as though an election could happen at any moment, and we did that for nearly two years. Because we had only an ad hoc (unelected) committee of organizers, itself constantly in flux, we were careful not to center our organizing on any one issue. We organized around a commitment to the idea of a graduate union but would not commit to what kind of union it would be until we had a way to represent everyone across our differences: international and domestic students, research assistants 
and teaching assistants, undergraduate TAs (who often work for different reasons than their graduate coworkers), parents, and students on all three of Columbia's campuses. In the nearly two years between our petition to the NLRB for recognition and our election for certification, graduate workers mobilized around rank-and-file initiatives to expand childcare subsidies and parental leave, demand timely maintenance (or fair remittance of rent) when construction left graduates in Columbia-owned housing without gas for more than three months, won additional summer funding opportunities, and guided international students through a horrible tax debacle for which Columbia refused to take responsibility. But only now, after our election victory, are we laying out a structure of representation in the union that will see us to the bargaining table - and a contract. President Donald Trump will have the power to appoint antiunion members to the national NLRB, which threatens the future of the Columbia decision and our collective bargaining rights. But because mentors from District 65 and UAW graduate campaigns at other universities made sure we built our union on a strong foundation of one-on-one organizing (in spite of the considerable time and resources such a campaign demands), we are ready to fight.

Although there was long-standing interest in unionizing at Harvard, it was only when Columbia filed their petition in December 2014 that a path forward was clear. Many union organizers came to the effort from the Harvard Teaching Campaign, which had delivered a petition with 2,273 signatures to the administration in April 2015 demanding smaller discussion section sizes. ${ }^{37}$ For the Harvard organizing committee, the choice to become part of the UAW was easy. We were excited to join our neighboring grad workers at University of Massachusetts-Boston, Amherst, and the University of Connecticut, who are affiliated with the UAW. Although we considered other international unions, the success and focus of the UAW effort at Columbia was inspiring. Finally, we were impressed by the unparalleled experience of the organizers we met, many of whom joined the UAW as graduate worker organizers from campaigns at the University of Washington, the University of Connecticut, and the University of Massachusetts. Although some graduate student activists, steeped in Occupy rhetoric of horizontalism, rejected a relationship with an international union, 90 per cent of student-organizers voted in September 2015 to begin an authorization card drive, and more than ninety percent supported moving forward with the UAW. Rather than campaign on any one issue, we campaigned on all of the issues that affect graduate workers, ranging from protection from sexual assault and overwork, to dental insurance and increased compensation, by collecting hundreds of testimonials that highlighted our "vision of a healthy Harvard." Whatever the final outcome of November's razor-thin vote, HGSU-UAW has established deep roots for the fight ahead. Student organizers across Harvard's campuses and programs are ready to continue building power toward recognition, a contract, and more just and sustainable organization of academic work.

When graduate workers at Columbia and Harvard took their first tentative steps toward unionization, they sought out, brought together, and elaborated 
existing communities of students across their campuses: the networks of support, collegiality, and friendship that see us through our long apprenticeship for academic work. Without the determination of the UAW and its organizers, however, the possibilities for collective action that are beginning to bear fruit now would have remained stunted, and we would have remained isolated in our different disciplines and labs and campuses. The long campaign at Columbia demanded a confrontation with the Brown decision, which required extensive and costly legal assistance. The UAW committed valuable resources - staff organizers, political networks that put pressure on Columbia and Harvard, and time - that were indispensable in keeping a committee of precarious workers together over the course of many months. However, the UAW committed more than resources to the struggle for graduate workers at private universities to have collective bargaining rights. Members of Local 2110-veterans of District 65-mentored us as we expanded, helping us shape a strategy with democratic integrity and the power to change our working conditions. Whatever the future holds, that empowerment has transformed our collective understanding of what the work of higher education is, and what it can be.

Our current campaigns are immediately rooted in the economic uncertainty that most of us face, whether inside or outside academia. The conditions that precipitated graduate unionization in the early 2000s flourished in the aftermath of the 2008 crisis. College graduates applied to graduate programs in record numbers to escape-or defer a reckoning with-collapsed labor markets and burdensome student loan repayments. ${ }^{38}$ At the same time, the recession entrenched trends, apparent since the mid-1970s, toward precarity in the academic labor market with a decline in full-time tenured instructional and senior research positions and a rise in the number of adjuncts and post-docs. $^{39}$

What has it meant for our campaigns at Columbia and Harvard to affiliate with an existing union? With the UAW? It has meant joining with organizers who were forged in the higher-ed clerical campaigns of the 1970s and 1980s and who had experience and institutional memory of building power at Columbia and Harvard reaching back before many of us were born. For our campaigns, dissatisfaction with the working conditions under which we labor, a sense that our work is both indispensable and undervalued, our aspirations as scholars and scientists, and growing anxieties about the future of the university all contributed to our decision to organize. But being part of the UAW has been essential for us to channel that desire into building strategic power around our labor, and that has made all the difference. Graduate workers at Columbia and Harvard have organized around their concerns as workers since the 1960s, but it was because of the labor movement, and the UAW in particular, that we became union workers in 2016. 


\section{NOTES}

1. Catie Edmondsun, "Graduate Teaching and Research Assistants Vote to Unionize," Columbia Spectator, December 9, 2016.

2. The count at Harvard was delayed for a month to resolve more than 1,200 challenge ballots cast by potentially eligible workers who were not on the list of voters that Harvard provided to the NLRB; Leah Yared, "Challenge Ballots Delay Student Unionization Vote," The Harvard Crimson, December 8, 2016.

3. In the following four months two other unions filed petitions for certification. The Yale grad workers in UNITE-HERE Local 33, veterans of sustained twenty-five year battle for recognition, filed their petition for a certification election on August 29, immediately after the NLRB decision. However, their proposal for microunits based on ten departments is still awaiting a decision from the NLRB; Ed Stannard, "Yale Grad Students File Petition Seeking Union Certification," New Haven Register, August 29, 20016. In early November, Duke student workers filed a petition with the Service Employees International Union (SEIU) on the heels of an ongoing campaign to win collective bargaining for the adjunct faculty; Jane Stancill, "Duke Graduate Students Seek Vote to Unionize," The News \& Observer, November 10, 2016.

4. Nicolaus Mills, "The Corporatization of Higher Education," Dissent 59 (September, 2012): 6-9. Brian Pusser, "Higher Education, the Emerging Market, and the Public Good," in Knowledge Economy and Postsecondary Education: Report of a Workshop, ed. Patricia Albjerg Graham and Nevzer G. Stacey (Washington, DC, 2002), 105-26; Robyn Ferrell, "Income Outcome: Life in the Corporate University," Cultural Studies Review 17 (2011): 166.

5. Kendall Powell, "The Future of the Postdoc," Nature 530 (2015): 144-47; the average age at which PIs receives their first R01 grant from the NIH has risen dramatically since the 1970s. Sally Rockey, "Our Commitment to Supporting the Next Generation," Rock Talk, Blog, National Institutes of Health Extramural Nexus, February 3, 2012. https://nexus.od.nih. gov/all/2012/02/03/our-commitment-to-supporting-the-next-generation/ (accessed February 13, 2017).

6. Aaron Bady and Mike Konczal, "From Master Plan to No Plan: The Slow Death of Public Higher Education," Dissent 59 (September, 2012), 10.

7. At Harvard, the concerns of student workers go back to the 1930s and 1940s, but little is known about these early efforts; "Lightened Burden for GI Teaching Fellows Guaranteed by Buck," Harvard Crimson, December 11, 1946.

8. Lee H. Simowitz, "Some Teaching Fellows are Organizing for Better Pay and Better Communications," Harvard Crimson, February 18, 1967.

9. Columbia University 97 NLRB 424 (1951). In 1970, private university employees were placed under the jurisdiction of the Board. Cornell University 183 NLRB 329, 74 LRRM 1269 (1970).

10. "Deans: IF's are Students, Not Employees," Harvard Crimson, May 26, 1967.

11. "Teaching Fellows Get Pay Hike," Harvard Crimson, January 7, 1971.

12. The records of the Harvard Graduate Student and Teaching Fellow Union are held at the Harvard University Archives. HUD. 3438.6000.

13. Jeremy S. Bluhm, "Bread \& Butter Battle at the Grad School," Harvard Crimson, June $15,1972$.

14. Ibid.

15. Dale S. Russakoff, "Grad Union Ends Organizing Efforts for Spring Term," Harvard Crimson, April 20, 1973.

16. Martin H. Malin, "Student Employees and Collective Bargaining," Kentucky Law Journal 69 (1981 1980): 1-35. Campaigns were active at other state universities, including Indiana, Illinois, Michigan, Minnesota, New York, Ohio, and Pennsylvania.

17. Lisa Ann Wunderlich Phillips, A Renegade Union: Interracial Organizing and Labor Radicalism, Working Class in American History (Urbana, IL, 2013). 1990.

18. "Inroads by Unions among Assistants in Graduate Study," New York Times, July 8,

19. Sharon Kurtz, Workplace Justice: Organizing Multi-Identity Movements, Social Movements, Protest, and Contention, vol. 15 (Minneapolis, 2002); Miriam Frank, Out in the Union: A Labor History of Queer America (Philadelphia, 2014). 
20. Richard W. Hurd, "Learning from Clerical Unions: Two Cases of Organizing Success," Labor Studies Journal XIV (1989): 3.

21. Ibid., 4.

22. Ibid., 8 .

23. New York University 332 NLRB 111 (2000).

24. Brown University 342 NLRB 42 (2004).

25. Henrik N. Dullea, "Cornell Graduate Assistants Reject Union Representation," Cornell Chronicle, October 25, 2002.

26. Shira Schoenberg, "Labor Board Rules TAs now Employees," Columbia Spectator, November 20, 2000.

27. Sarah M. Shwairi, "In the Name of Solidarity," Columbia Spectator, January 31, 2002. $8,2002$.

28. Derrick Higginbotham, "Rupp's Message is Anti-Union," Columbia Spectator, March

29. Sarah M. Shwairi, "In the Name of Solidarity," Columbia Spectator, January 31, 2002.

30. Scott Smallwood, "Union? No Thanks," The Chronicle of Higher Education 48(36) (May 17, 2002): A12-15.

31. Colleen Flaherty, "For Your Anti-Union Information," Inside Higher Ed online, August 30, 2016, insidehighered.com (accessed January 13, 2017).

32. Smallwood, "Union? No Thanks."

33. Jonathan Earle, "Union Contract Deadline Looms Closer, but Negotiators Refuse to Compromise," Columbia Spectator, October 12, 1988.

34. Amba Datta, "Hearings on TAs' Right to Unionize Commence," Columbia Spectator, April 20, 2001. "Edward A. Brill, Partner," http://www.proskauer.com/professionals/edwardbrill/ (accessed 10 December 2016).

35. The distinction between campaigns that lost momentum and those that stayed live is largely a material, not a moral, one. Campaigns supported by international unions that represented other (clerical and/or service) workers on campus (most notably GESO-UNITE-HERE! - now Local 33 - at Yale and GSOC-UAW at NYU) had greater local capacity in terms of funds and organizing labor, paid and unpaid, to maintain a greater level of continuity in organizing on the ground between the Brown and Columbia decisions. However, apart from the UAW, no other international was prepared to petition the NLRB for recognition in defiance of university administrators, and thus to take on the legal fight against Brown that such a challenge would provoke; Josh Eidelson, "Will the NLRB Let Down Graduate Workers Again?" Working in These Times blog, December 20, 2011, http://inthesetimes.com/working/entry/12450/will_the_ nlrb_let_graduate_student_workers_down_again/ (accessed December 9, 2016).

36. But even without legal recognition, graduate unions wrested important improvements from university administrations. Furthermore, graduate unions provided a forum for critical discussion and support around issues that university administrations would not address, including, most notably, sexual harassment and assault; Sarah Matthiesen, "The Conversation the Ivies Won't Have," Jacobin online, August 14, 2014, Jacobinmag.com (accessed January 13, 2017).

37. Karl M. Aspellund, "Teaching Campaign Delivers Section Cap Petition to Mass. Hall," Harvard Crimson, April 22, 2015.

38. Applications to graduate schools continued to grow in number, exceeding two million for the first time in 2013 and doing so again in 2014; Jeff Alum and Hironao Okahana, Graduate Enrollment and Degrees: 2004-2014 (Washington, DC, 2014), 9; Hironao Okahana, Keonna Feaster, and Jeff Allum, Graduate Enrollment and Degrees: 2005-2015 (Washington, DC, 2016), 3.

39. Steven Shulman et al., "Higher Education at a Crossroads: The Economic Value of Tenure and the Security of the Profession," Academe 102 (2) (2016): 13; Scott A. Ginder, Janice E. Kelly-Reid, and Farrah B. Mann, Enrollment and Employees in Postsecondary Institutions, Fall 2014 (Washington, DC, 2015); David Cyranoski et al., "The PhD Factory: The World is Producing More PhDs Than Ever Before: Is it Time to Stop?" Nature 472 (2011): 277; Kendall Powell, "The Future of the Postdoc," Nature 520 (2015): 144-47. 